
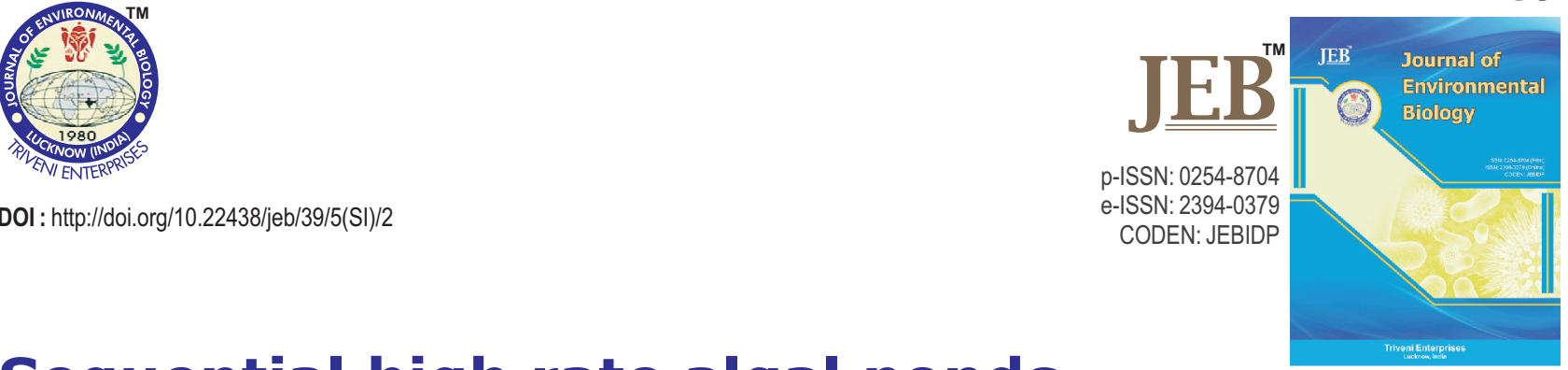

\title{
Sequential high rate algal ponds operation for enhanced treatment of organic wastewater
}

Authors Info

M. Kishi" ${ }^{1 *}$ H. Takee', M. Kawai', N. Nagao ${ }^{2}$ and T. Toda ${ }^{1}$

'Graduate School of Engineering, Soka University, 1-236 Tangi-cho, Hachioji, Tokyo 192-8577, Japan

'Laboratory of Marine Biotechnology, Institute of Bioscience, Universiti Putra Malaysia, 43400 Serdang, Selangor Darul Ehsan, Malaysia

*Corresponding Author Email : masa-kishi@soka.gr.jp

Key words

Algal-bacterial consortium Algal pond Aquaculture wastewater Sequential HRAP operation Valorization

Publication Info

Paper received : 09.06.2017

Revised received : 19.09.2017

Accepted : 28.12.2017

\section{Abstract}

Aim: Treatment of aquaculture wastewater often experiences fluctuations in chemical oxygen demand, causing insufficient performances. This study aimed to evaluate the stability of sequential high rate algal ponds in treating simulated aquaculture wastewater.

Methodology: Two $1 \mathrm{~m}^{3}$ high rate algal ponds were sequentially connected to treat simulated aquaculture wastewater, which was prepared through diluting solubilized food waste (chemical oxygen demand: 300 $\mathrm{mgl}^{-1}$ ). The hydraulic retention time was set at 10 days for each reactor.

Results: More than $80 \%$ of influent organics and nearly $100 \%$ of nutrients (ammonium, nitrate, and phosphate) were removed from the effluent. While the oxygen demand removal in Pond 1 was incomplete around Day 8 , Pond 2 was successful in removing untreated biodegradable oxygen demand from Pond 1 effluent. In addition, the sequential HRAP operation reduced bacterial biomass in the algal biomass of Pond 2 owing to the low organic loading on the second pond.

Interpretation: These results indicate that sequential HRAP operation has advantages not only in stable wastewater treatment performance, but also in the valorization of algal biomass produced through aquaculture wastewater treatment.

\section{Sequential pond operation}

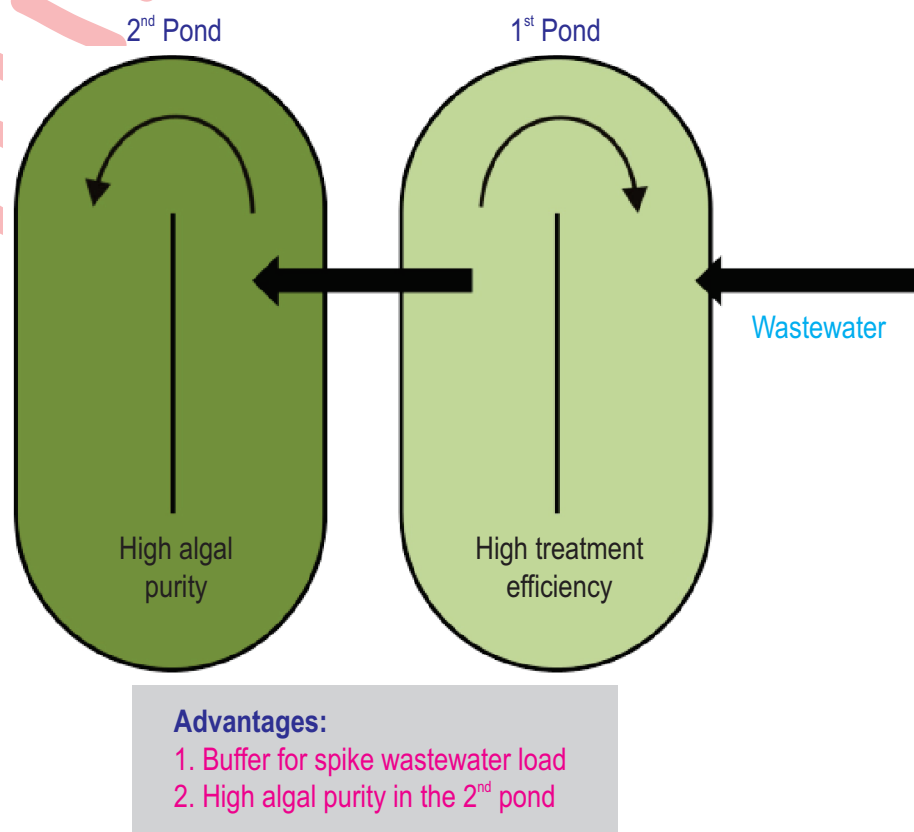




\section{Introduction}

With the rapid growth of aquaculture industry, the impacts of aquaculture wastewaters and sludge on the environment is a matter of concern (FAO, 2014). Aquaculture wastes contain high concentrations of organic matter, mainly composed of faeces and excess feeds, and nitrogen (Wright, 1995; Crab et al., 2007). Intrusion of these wastes into the natural environment causes mangrove degradation, salt water intrusion, pollution and disease outbreaks (Paul and Vogl, 2011).

Environmental issues are especially severe in Southeast Asia, where many fish farmers cannot afford extensive wastewater treatment despite the rapid growth of aquaculture industry. Instead, the treatment of these aquaculture wastes has been only limited to simple treatment such as aerobic digestion of labile organic compounds in the sludge. In order to improve the water quality, in previous researches the so-called recirculating aquaculture system (RAS) has been studied (Martins et al., 2010), which is a combination of various filtration methods, composting (Marsh et al., 2005), and anaerobic digestion (Mirzoyan et al., 2010), to minimize water usage and environmental pollution. However, a low-cost and less energyintensive treatment technology are highly needed.

As an alternative wastewater treatment method, algalbacterial system has been studied (Oswald et al., 1953; Muñoz and Guieysse, 2006; Park et al., 2011). This system utilizes a symbiotic relationship between microalgae and bacteria, where bacteria decompose organic wastes using oxygen produced by algal photosynthesis. At the same time, the carbon dioxide produced through bacterial waste decomposition enhances the growth of microalgae. In addition, both microalgae and bacteria utilize dissolved nutrients to produce biomass. This algal-bacterial system is commonly operated with high rate algal ponds (HRAPs), of which capital costs are less than half and operational costs are less than one fifth compared to those of activated sludge systems (Park et al., 2011). Moreover, the produced biomass can be applied as feed for aquaculture or livestock (Wang, 2003; Shpigel and Neori, 2007; De Schryver et al., 2008), or as substrates of anaerobic digestion for energy recovery (Colletet al., 2011).

One of the challenges of HRAPs, however, is the instability of the treatment efficiency with variations in the environmental conditions. While HRAPs are known to be relatively tolerant to shock loading (Craggs et al., 2004a), COD treatment efficiency drastically decreases when dissolved oxygen (DO) concentration is reduced owing to consistently high COD loading and/or low irradiance (de Godos et al., 2009). de Godos et al. (2009) reported that a HRAP treatment of piggery manure performed well $(76 \%$ COD removal) even with a high influent load of over $3 \mathrm{~g}-\mathrm{COD} \mathrm{l}^{-1}$ during summer. However, when solar irradiance decreased, COD removal efficiency was reduced to approximately $50 \%$ compared with a similar COD load. Another challenge of HRAPs is the low-quality algal biomass that contains a large fraction of bacteria owing to the treatment of organic-rich wastewater, which is difficult to be used except for energy production. These two challenges could be solved by setting up a two sequential HRAPs. Even if fluctuations in the influent load cause instability in the first pond, the second pond can remove compounds that are untreated in the first one. Furthermore, the reduction of organic compounds in the second pond may enable microalgae-dominated biomass production.

Therefore, in this study a sequential HRAP operation conducted and further the performance of COD and nutrient removal characteristics was evaluated. Additionally, the aim was to clarify the microalgal and bacterial biomass production characteristics in a sequential HRAP process.

\section{Materials and Methods}

Design and operation of high rate algal ponds (HRAPs): Two raceway-type HRAPs with an active volume of $1.2 \mathrm{~m}^{3}$, surface area of $4.1 \mathrm{~m}^{2}$, and depth of $0.3 \mathrm{~m}$ were constructed with FRP, and placed on a rooftop at the Faculty of Science and Engineering,

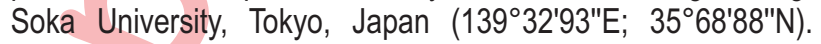
Mixing was implemented with paddle wheels powered by a motor (Fig. 1). The ponds were covered with transparent acrylate lids to avoid dilution with precipitation. The HRAPs were heated with titanium heaters or cooled with a cool unit when the water temperature reached $15^{\circ} \mathrm{C}$ or $30^{\circ} \mathrm{C}$, respectively.

The experiment was conducted for 30 days i.e., from $5^{\text {th }}$ August to $4^{\text {th }}$ September (30 days). Artificial wastewater was supplied to Pond 1 at a hydraulic retention time (HRT) of 10 days. The effluent of Pond 1 was supplied to Pond 2 directly without filtration or sedimentation at the same HRT as Pond 1 (10 days). samples were taken at noon every 2 to 3 days.

Feedstock preparation : To simulate aquaculture wastewater with high concentration of COD, the feedstock wastewater was prepared by solubilizing food waste, which has a high volatile suspended solid and protein content. For the preparation of the solubilized food waste, mixed food waste obtained from Ohmura Shoji Inc., was firstly milled to $2-3 \mathrm{~mm}$ and frozen for storage. Every 5-6 days, the frozen milled waste was thawed and mixed with warm tap water at $1: 4(\mathrm{w} / \mathrm{w})$, ratio and the mixture was filtered through a 250-300 $\mu \mathrm{m}$ metal screen to obtain the solubilized food

Table 1: Chemical characteristics of the solubilized food waste

\begin{tabular}{lll}
\hline Parameter & Value & Units \\
\hline Salinity & 2.6 & \\
Suspended solids (SS) & 7.4 & $\mathrm{gl}^{-1}$ \\
Total chemical oxygen demand (TCOD) & 27.0 & $\mathrm{gl}^{-1}$ \\
Soluble chemical oxygen demand (SCOD) & 16.5 & $\mathrm{gl}^{-1}$ \\
Total dissolved nitrogen (TDN) & 2.5 & $\mathrm{gl}^{-1}$ \\
Total dissolved phosphate(TDP) & 0.5 & $\mathrm{gl}^{-1}$ \\
\hline
\end{tabular}

All the values are expressed in $\mathrm{gl}^{-1}$, except for salinity 
(a)
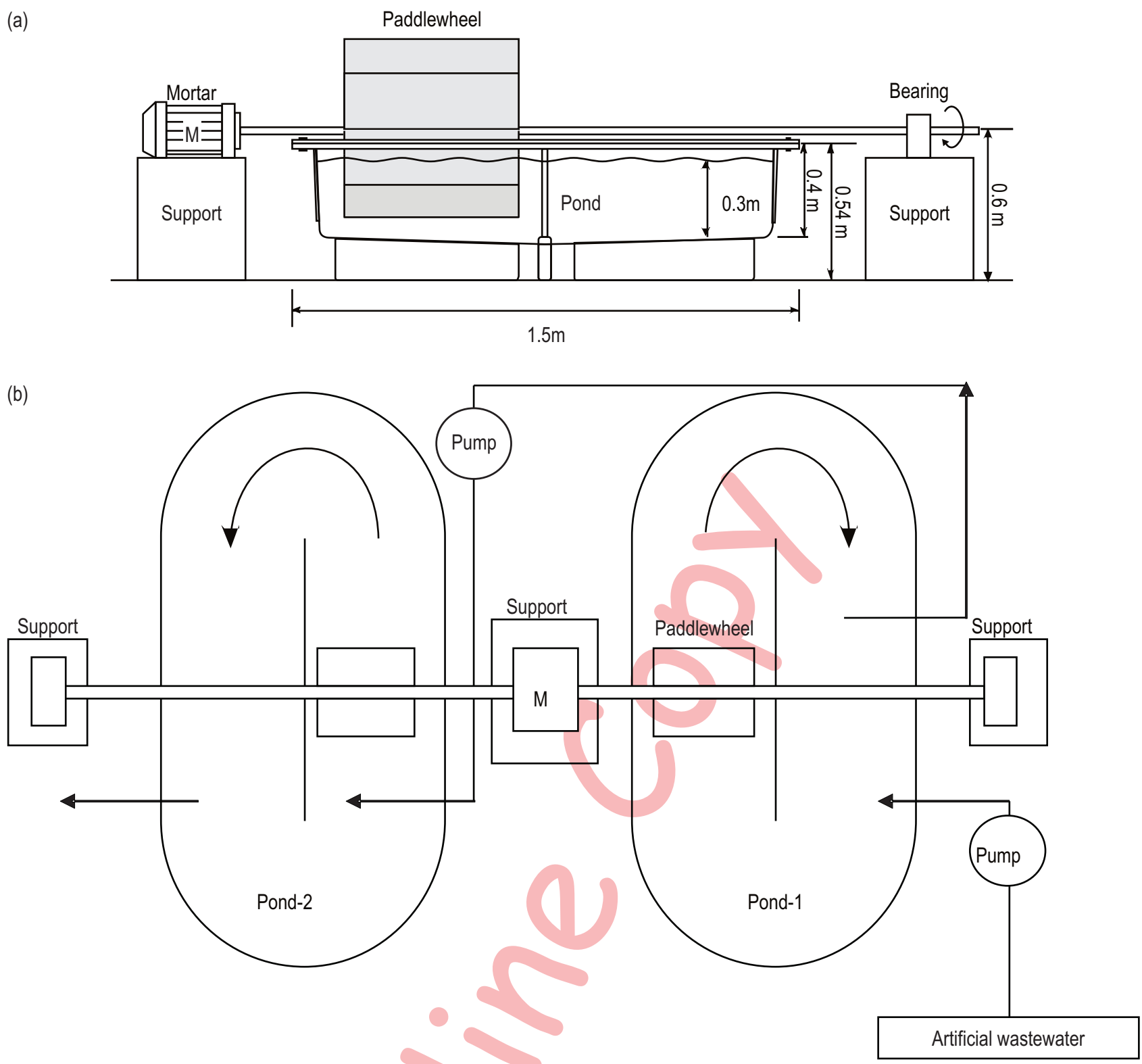

Fig. 1 : Schematic diagram of the top and side view of the HRAPs. (a) Side view of Pond-1 and (b) Top view of the whole experimental set

waste. The average chemical characteristics of the solubilized food waste are summarized in Table 1. Every day at noon, the solubilized food waste was supplied to a feed storage tank and diluted with tap water to adjust the chemical oxygen demand

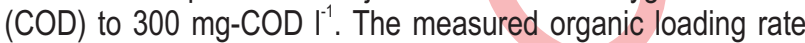
(OLR) to the Pond 1 was $9.1 \pm 2.2 \mathrm{~g}-\mathrm{COD} \mathrm{m^{-2 }} \mathrm{d}^{-1}$.

Analytical procedures : At every inlet and outlet, samples were taken every 2-3 days and measured for $\mathrm{pH}, \mathrm{DO}, \mathrm{COD}$, nutrients $\left(\mathrm{NO}_{3}-\mathrm{N}, \mathrm{NH}_{4}-\mathrm{N}\right.$, and $\left.\mathrm{PO}_{4}-\mathrm{P}\right)$, chlorophyll $a$ and bacterial cell counts.

The $\mathrm{pH}$ was measured with a portable $\mathrm{pH}$ meter (Shindengen, KS723, Japan). Bacterial cells were counted with a fluorescent microscope (Zeiss, Germany) using a fluorescent dye (SYBR Gold, Thermo Fisher, USA) (Shibata et al., 2006). Nutrients were analyzed with a nutrient analyzer (SWAAT, BLTEC, Japan). Chlorophyll a samples on glass fiber filters were first extracted with $\mathrm{N}, \mathrm{N}$-dimethylformamide (Suzuki and Ishimaru, 1990), and measured with a fluorometer (Model 10AU, Turner Design, USA) as described by Welshmeyer (1994). The COD was estimated following the standard methods of APHA, (2017).

Water temperature inside the ponds was monitored with data loggers (RTR 51, T\&D Corp.), and daily irradiance was measured with a pyranometer (MS-402, EKO Instrument) and logged with a multi-system logger (CADAC3 model 9350A, Eto 
Denki Co.). Photosynthetically available photon flux density was also measured at sampling with a PAR sensor (QSPL2101, Biospherical Instruments Inc.).

\section{Results and Discussion}

Environmental and biological factors: The average solar irradiation during the experimental period was $18.8 \pm 5.4 \mathrm{MJ} \mathrm{m}^{-2} \mathrm{~d}^{-1}$
(Fig. 2a), which was similar to the annual average values in Southeast Asia, such as $17.3 \mathrm{MJ} \mathrm{m}^{-2} \mathrm{~d}^{-1}$ in Indonesia (Hadiyanto et al., 2012) and $18.7 \mathrm{MJ} \mathrm{m}^{-2} \mathrm{~d}^{-1}$ in Kota Kinabalu, Malaysia (Rahim et al., 2012). Solar irradiation decreased during precipitation events, which occurred on Day 1, 9, 12, 13 and 27-30. The water temperature similarly decreased during raining events in the beginning (Day 1-10 and 27), but the average was maintained
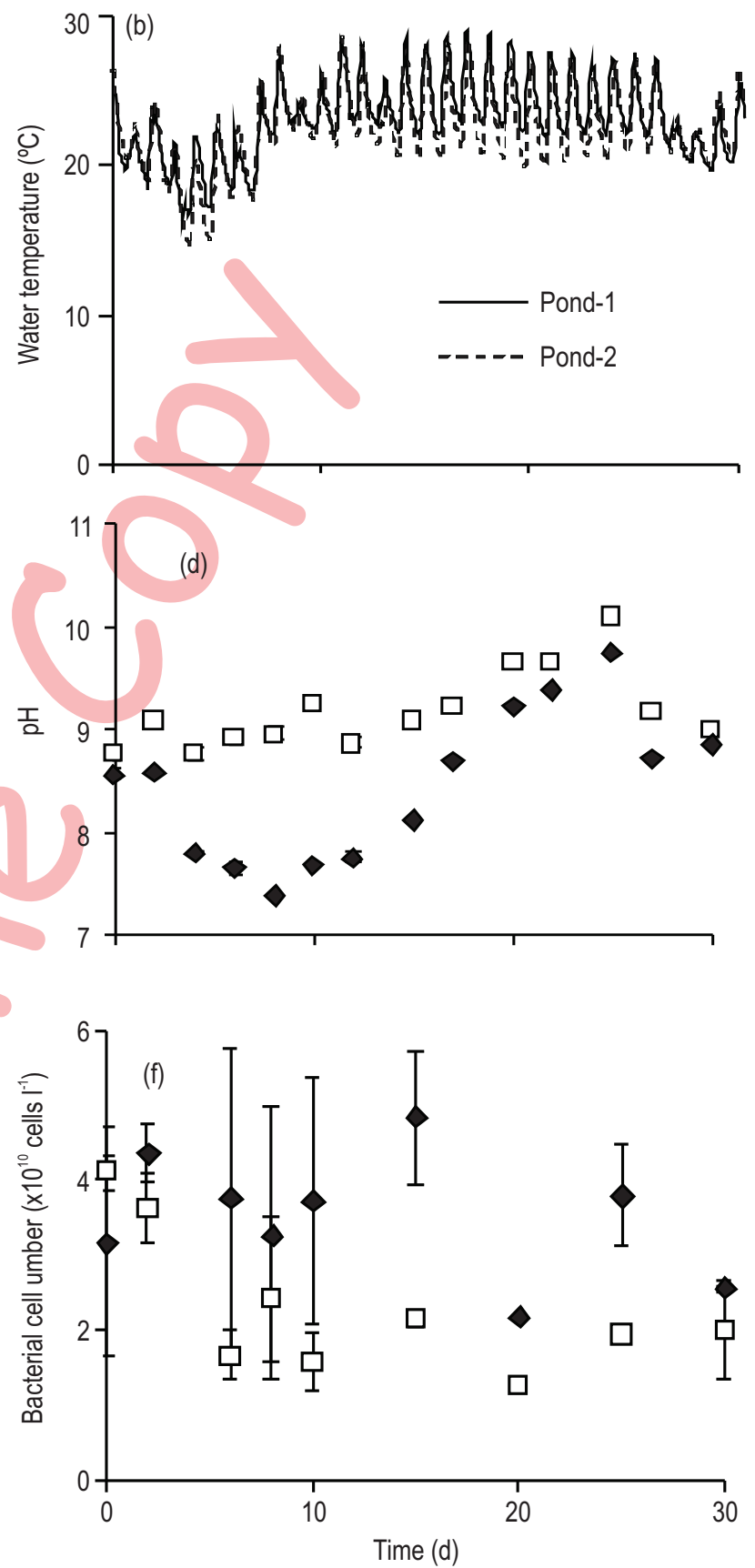

Fig. 2 : Environmental conditions and biological parameters during sequential HRAPs operation. (a) solar irradiation and day length, (b) water temperature, (c) dissolved oxygen, (d) pH, (e) chlorophyll a and (f) bacterial cell number 
over $17^{\circ} \mathrm{C}$ (Fig. $2 \mathrm{~b}$ ). The water temperature remained stable between Day 7 to 26 . There was no statistical difference in the average temperature between Pond- 1 and $2(p>0.1$; student's ttest).

The DO fluctuated between 3.4 and $14.6 \mathrm{mg} \mathrm{l}^{-1}$ (Fig. 2c). Pond 1 tended to have lower DO concentrations, probably owing to the higher OLR than Pond 2, causing active decomposition of organic compounds. On the other hand, Pond 2 had a relatively stable DO due to low OLR. The DO in both ponds exceeded the saturation level (approximately $8 \mathrm{mg} \mathrm{I}^{-1}$ at $25^{\circ} \mathrm{C}$ ) after Day 15 when solar irradiation remained at high levels and chl. a concentration began to increase, indicating a high rate of photosynthetic oxygen production (Fig. $2 \mathrm{e}$ ). The pH followed a similar trend as $\mathrm{DO}$ (Fig. $2 \mathrm{~d}$ ). The reason in pH fluctuations was probably due to $\mathrm{CO}_{2}$ production and uptake by bacterial respiration and photosynthetic carbon fixation. While bacterial respiration consumes $\mathrm{O}_{2}$ to produce $\mathrm{CO}_{2}$, the opposite occurs during photosynthesis, and thus, increase or decrease in DO coincide with $\mathrm{pH}$. Both DO and $\mathrm{pH}$ decreased after Day 27, probably owing to decreased solar irradiation because of heavy precipitation.

The Chl. a concentration gradually increased in both ponds (Fig. 2e), but decreased after Day 27 when heavy rain probably washed some algal biomass out of the ponds. The average bacterial cell number was $3.51 \pm 0.82$ and $2.30 \pm 0.95$ $\times 10^{10}$ cells I $^{-1}$ for Pond 1 and 2 , respectively. The bacterial cell number in Pond 1 was relatively higher, while that of Pond 2 decreased to less than half at the end of the experiment (Fig. 2f). The average Chl. a to bacteria ratios were $2.9 \pm 3.1$ and $8.1 \pm 6.2$ $\times 10^{-3} \mathrm{pg}$-Chl.a cell ${ }^{-1}$ for Pond 1 and 2, respectively. Assuming a rough approximate of $\mathrm{Chl}$. a to carbon ratio of 0.02 (Cloern et al., 1995) and carbon content in algal dry weight $0.5 \mathrm{gC} \mathrm{g}{ }^{-1} \mathrm{~d}$. wt. (Douskova et al., 2008; Jacob-Lopes et al., 2010; Ho et al., 2010), the bacterial cells to algal dry weight ratios were 3.4 and 1.2 cells $\mathrm{g}^{-1} \mathrm{~d}$. wt. for Pond 1 and 2 , respectively. These results indicate that Pond 2 had a higher purity of algal biomass.

The difference in biomass purity can be attributed to the difference in OLR. While Pond 1 received a high COD concentration (130-370 mg-COD l-1), Pond-2 received the effluent of Pond 1 with a lower COD (24-64 mg-COD l-1; Fig. 3-a,b). In Pond-1, COD removal efficiency remained $80 \%$ or higher throughout the experimental period (Fig. 3c), indicating that bacteria were actively growing. On the other hand, the COD removal efficiency in Pond 2 was less than $30 \%$, except for few days. These results imply that Pond-2 mostly received less degradable organic compounds, thus minimizing the proliferation of bacteria, and instead microalgae dominated in Pond-2.

Nutrient removal: The average influent $\mathrm{NH}_{4}-\mathrm{N}$ and $\mathrm{NO}_{3}-\mathrm{N}$ concentration were 2.7 and $1.4 \mathrm{mg} \mathrm{l}^{-1}$, respectively (Fig. 4a, b). The average effluent $\mathrm{NH}_{4}-\mathrm{N}$ and $\mathrm{NO}_{3}-\mathrm{N}$ concentration were less than 0.15 and $0.02 \mathrm{mg} \mathrm{l}^{-1}$ (Fig. 4c, d). Both ammonium $\left(\mathrm{NH}_{4}-\mathrm{N}\right)$ and nitrate $\left(\mathrm{NO}_{3}-\mathrm{N}\right)$ were mostly removed in the first pond, and the average removal efficiencies were 97 and $99.6 \%$ for $\mathrm{NH}_{4}-\mathrm{N}$ and $\mathrm{NO}_{3}-\mathrm{N}$, respectively, in Pond 1 (Fig. 4e, f). Since the influent concentrations of $\mathrm{NH}_{4}-\mathrm{N}$ and $\mathrm{NO}_{3}-\mathrm{N}$ were extremely low in Pond-2

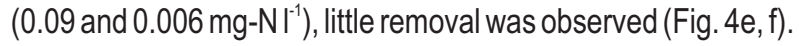
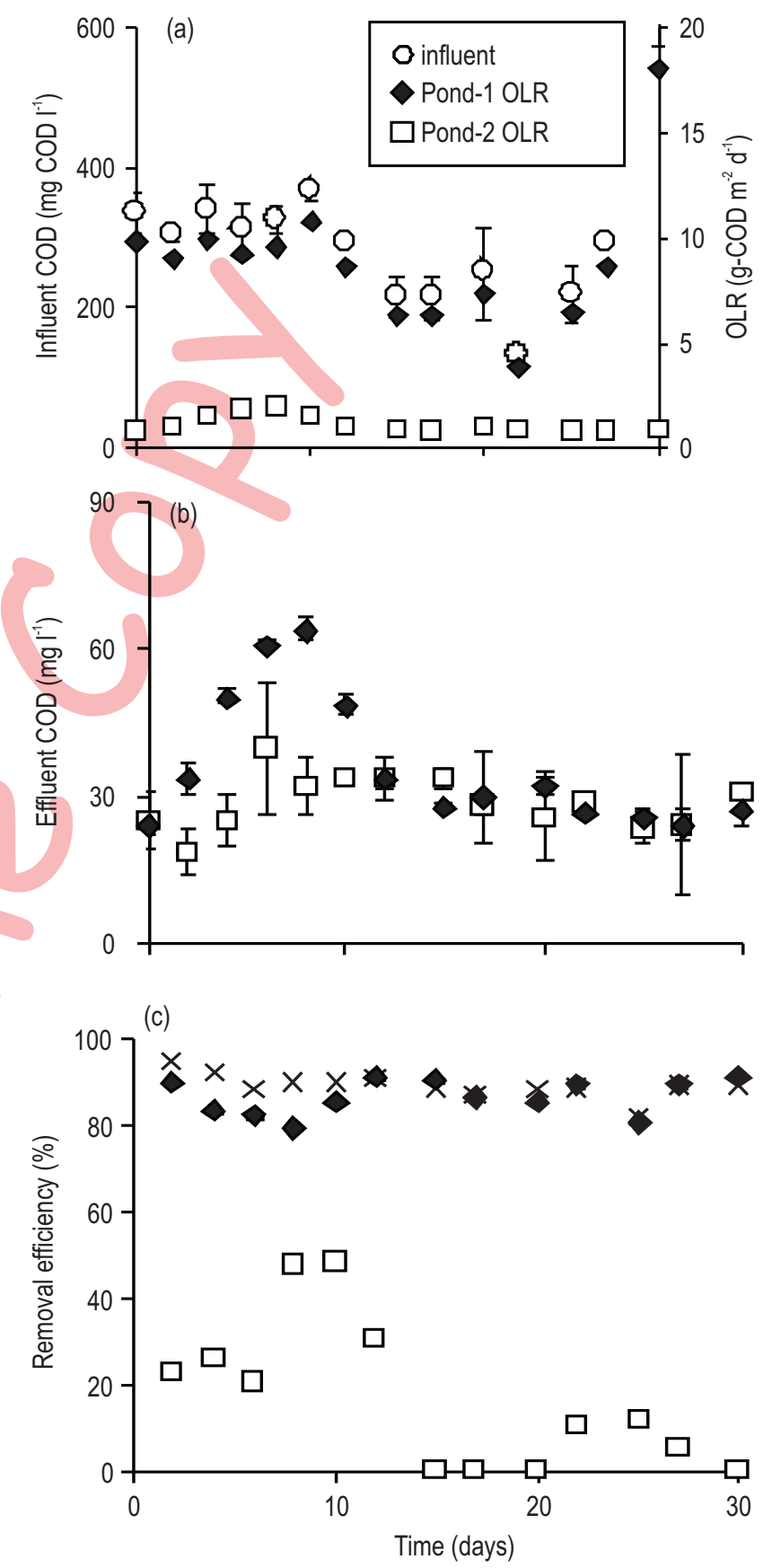

Fig. 3 : (a) Influent chemical oxygen demand (COD; $\bigcirc)$ and OLR, (b) effluent COD, and (c) COD removal rate of Pond-1 ( ) , Pond-2 ( $\square$ ) and total $(x)$ 

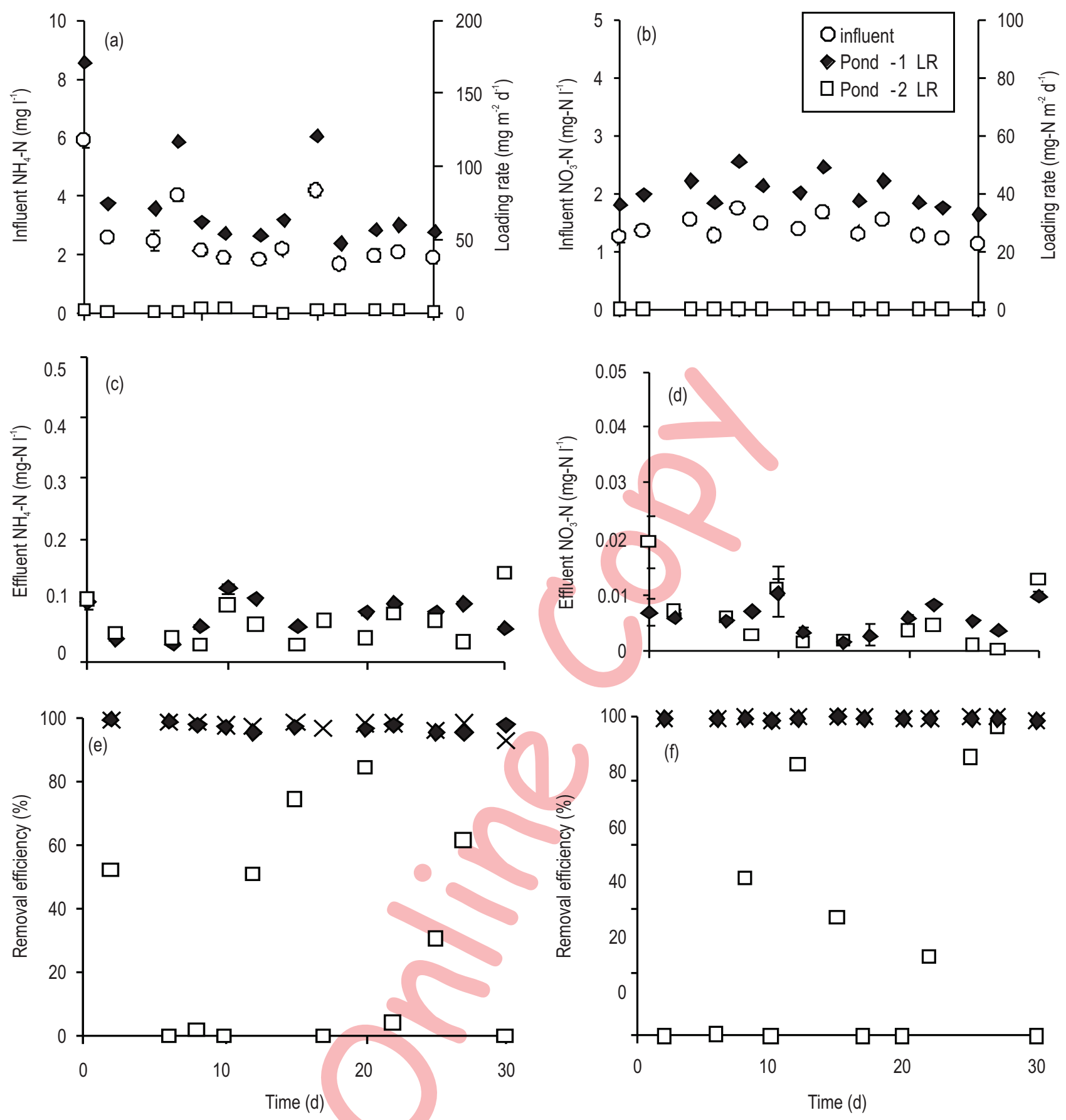

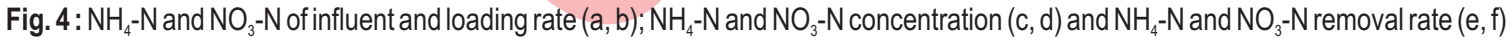

The average influent $\mathrm{PO}_{4}-\mathrm{P}$ concentration was $2.6 \mathrm{mg} \mathrm{I}^{-1}$ (Fig. 5a), and the average effluent concentration was less than $0.05 \mathrm{mg} \mathrm{l}^{-1}$ (Fig. 5b). The removal efficiency of phosphate $\left(\mathrm{PO}_{4}-\mathrm{P}\right)$ in Pond-1 was similar to other nutrients, and $99 \%$ of influent $\mathrm{PO}_{4}-\mathrm{P}$ was removed in the first pond (Fig. $5 \mathrm{C}$ ). In contrast to $\mathrm{NH}_{4}-\mathrm{N}$ and $\mathrm{NO}_{3}-\mathrm{N}$, the $\mathrm{PO}_{4}-\mathrm{P}$ removal efficiency also exceeded $80 \%$ except for a few days (Fig. $5 \mathrm{c})$. One of the possible reasons is precipitation of $\mathrm{PO}_{4}-\mathrm{P}$ salt induced by high $\mathrm{pH}(\sim 9-10)$, as reported in other HRAP studies (Deviller et al., 2004; Metaxa et al., 2006), which occurred in Pond-2 (Fig. 2d).

Effect of sequential HRAP operation: This study demonstrated that the sequential operation of HRAP has two advantages: algal biomass purity and treatment stability. Firstly, algae-dominated biomass could be created in the latter pond owing to the removal of organic compounds in the first pond (Fig. 3b). The removal of 

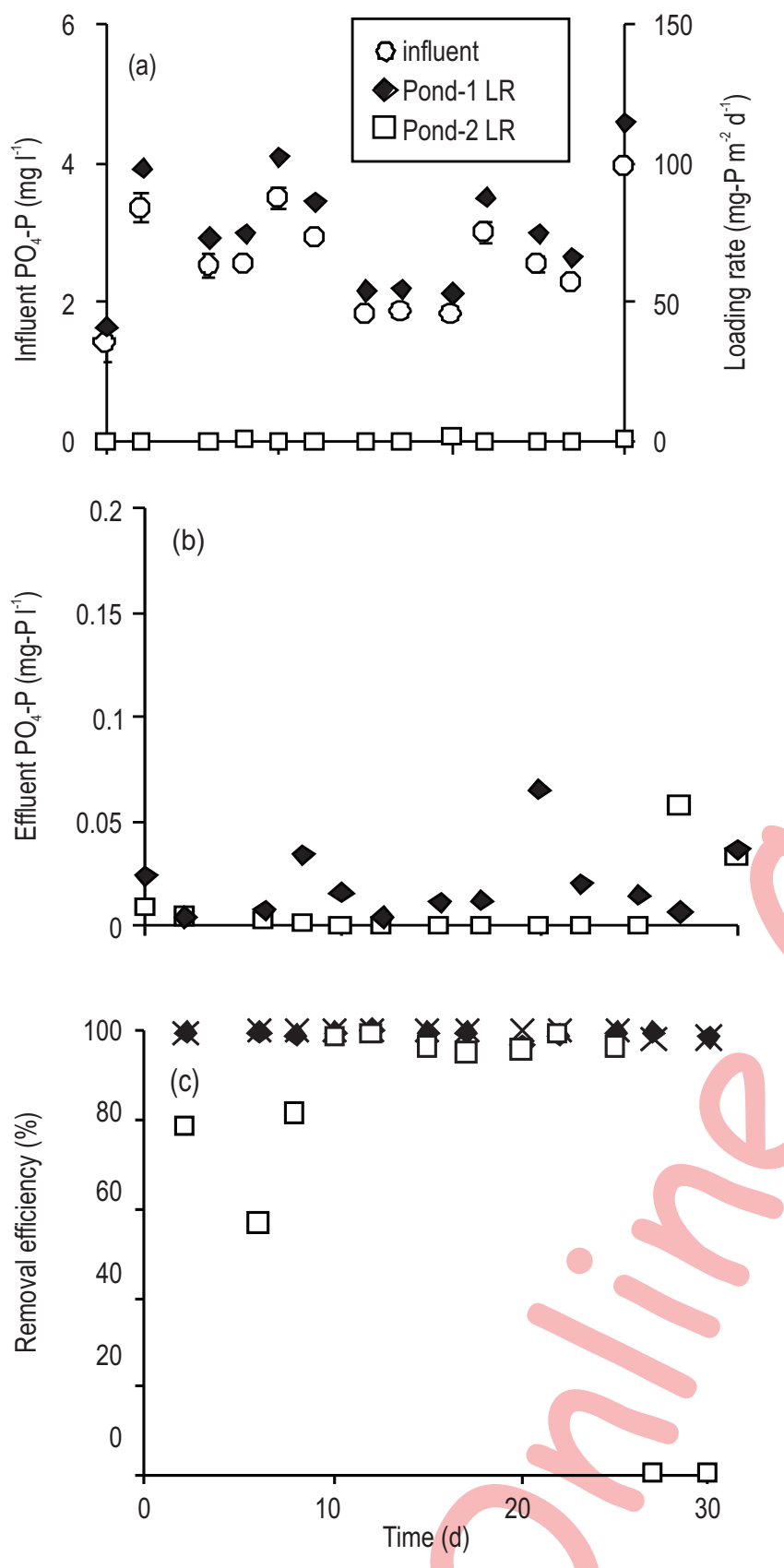

Fig. 5 : $\mathrm{PO}_{4}-\mathrm{P}$ of influent $(\bigcirc)$ and $\mathrm{PO}_{4}-\mathrm{P}$ loading rate (a) $\mathrm{PO}_{4}-\mathrm{P}$ concentration (b) and $\mathrm{PO}_{4}-\mathrm{P}$ removal rate $(\mathrm{c})$ of Pond- $1(\bullet)$, Pond-2 $(\square)$ and total $(x)$

labile organic compounds in the Pond 2 influent contributed to the reduction of bacterial abundance in the Pond-2 (Fig. 2f). The long retention time (10 days) may have also contributed to the decrease of the bacterial cell number in Pond 2 by exposing bacteria to strong sunlight (Benchokroun et al., 2003; Craggs et al., 2004b; García et al., 2008). In contrast, algae continued to grow in Pond 2 (Fig. 2e) probably by using the remaining nutrients. The resulting algal biomass purity may elevate its value to be used as feed or other products. An acceptable level of microbial contamination for human intake depends on the country. As one of the strictest examples, Japanese regulation allows products with less than $0.005 \times 10^{6}$ colony forming units (CFU) $\mathrm{g}^{-1} \mathrm{~d}$. wt. (Lembi and Waaland, 1988). Other regulations vary from $0.1 \times 10^{6} \mathrm{CFU} \mathrm{g}^{-1} \mathrm{~d}$. wt. in France to $100 \times 10^{6} \mathrm{CFU} \mathrm{g}^{-1} \mathrm{~d}$. wt. in Sweden (Lembi and Waaland, 1988; Becker, 1994; Görs et al., 2010). While the bacterial abundance in the current study was still high in both ponds ( 1.2 to $3.4 \times 10^{12}$ cells $\mathrm{g}^{-1} \mathrm{~d}$. wt.), the bacterial abundance decreased by almost three-fold in the second reactor. Since the extremely low nutrient concentrations could have limited the growth of algae, optimization of OLR and HRT may improve the microalgal biomass purity, as well as algal biomass productivity.

Secondly, a sequential operation enables the stable removal of nutrients and organic compounds. For example, the average effluent COD concentrations in Pond 2 was $29 \pm 5 \mathrm{mg}$ $\operatorname{COD~} L^{-1}$, which was lower than previous studies of urban waste waters with similar influent COD (260-268 mg-COD $\left.{ }^{-1}\right)$ : 79-170

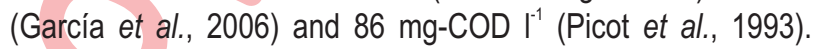
Furthermore, treatment instability of the first pond can be buffered by including a secondary pond. For instance, Pond 2 removed untreated COD during periods of instability in Pond 1 on around Day 8 (Fig. 3b), when low DO (Fig. 2c) limited the bacterial decomposition of organic compounds due to the low irradiance and the low chl. a concentrations (Fig. 2b,e).

The sequential HRAP operation was effective for the treatment of relatively concentrated wastewaters with large fluctuations in loading rates. Further knowledge on the effects of higher loading rates on treatment efficiencies and biomass production would improve the feasibility and applicability of the sequential process.

\section{Acknowledgments}

This research was supported by Japan Science and Technology Agency (JST)/Japan International Cooperation Agency (JICA), Science and Technology Research Partnership for Sustainable Development (SATREPS). Authors would like to express gratitude to the Kitano Sewage Treatment Plant (Tokyo, Japan) for providing the activated sludge, and to Ohmura Shoji Inc. for providing food waste used in this research.

\section{References}

APHA, WEF and AWWA: Standard Methods for the Examination of Water and Wastewater. $23^{\text {rd }}$ Edn., pp. 1504 (2017).

Benchokroun, S., B. Imziln and L. Hassani: Solar inactivation of mesophilic Aeromonas by exogenous photooxidation in high-rate algal pond treating waste water. J. Appl. Microbiol., 94, 531-8 (2003).

Becker, E.W.: Microalgae: Biotechnology and Microbiology. Cambridge University Press (1994). 
Cloern, J.E., C. Grenz and L. Vidergar-Lucas: An empirical model of the phytoplankton chlorophyll: Carbon ratio-the conversion factor between productivity and growth rate. Limnol. Oceanogr. 40, 1313-1321 (1995).

Collet, P., A. Hélias, L. Lardon, M. Ras, R.-A. Goy and J.P. Steyer: Lifecycle assessment of microalgae culture coupled to biogas production. Bioresour. Technol., 102, 207-214 (2011).

Crab, R., Y. Avnimelech, T. Defoirdt, P. Bossier and W. Verstraete: Nitrogen removal techniques in aquaculture for a sustainable production. Aquaculture, 270, 1-14 (2007).

Craggs, R.J., J.P. Sukias, C.T. Tanner and R.J. Davies-Colley: Advanced pond system for dairy-farm effluent treatment. New Zeal. J. Agric. Res., 47, 449-460 (2004a).

Craggs, R.J., A. Zwart, J.W. Nagels and R.J. Davies-Colley: Modelling sunlight disinfection in a high rate pond. Ecol. Eng., 22, 113-122 (2004b).

Deviller, G., C. Aliaume, M.A.F. Nava, C. Casellas and J.P. Blancheton: High-rate algal pond treatment for water reuse in an integrated marine fish recirculating system: Effect on water quality and sea bass growth. Aquaculture, 235, 331-344 (2004).

Douskova, I., J. Doucha, K. Livansky, J. Machat, P. Novak, D. Umysova, V. Zachleder and M. Vitova: Simultaneous flue gas bioremediation and reduction of microalgal biomass production costs. Appl. Microbiol. Biotechnol., 82, 179-185 (2008).

FAO: The State of World Fisheries and Aquaculture (2014).

García, J., B.F. Green, T. Lundquist, R. Mujeriego, M. Hernández-Mariné and W.J. Oswald: Long term diurnal variations in contaminant removal in high rate ponds treating urban wastewater. Bioresour. Technol., 97, 1709-1715(2006).

García, M., F. Soto, J.M. González and E. Bécares: A comparison of bacterial removal efficiencies in constructed wetlands and algaebased systems. Ecol. Eng., 32, 238-243 (2008).

de Godos, I., S. Blanco, P.A. García-Encina, E. Becares and R. Muñoz: Long-term operation of high rate algal ponds for the bioremediation of piggery wastewaters at high loading rates. Bioresour. Technol., 100, 4332-4339 (2009).

Görs, M., R. Schumann, D. Hepperle and U. Karsten: Quality analysis of commercial Chlorella products used as dietary supplement in human nutrition. J. Appl. Phycol., 22, 265-276 (2010).

Hadiyanto, S.P. Hadi and N.A. Utama: Research and Development on Energy and Environment in Indonesia (2012).

Ho, S.H., W.M. Chen and J.S. Chang: Scenedesmus obliquus CNW-N as a potential candidate for $\mathrm{CO}_{2}$ mitigation and biodiesel production. Bioresour. Technol., 101, 8725-8730 (2010).

Jacob-Lopes, E., C.H. Gimenes Scoparo, M.I. Queiroz and T.T. Franco: Biotransformations of carbon dioxide in photobioreactors. Energy Convers. Manag., 51, 894-900 (2010).

Lembi, C.A. and J.R. Waaland: Algae and Human Affairs. Cambridge University Press (1988).

Marsh, L., S. Subler, S. Mishra and M. Marini: Suitability of aquaculture effluent solids mixed with cardboard as a feedstock for vermicomposting. Bioresour. Technol., 96, 413-418 (2005).

Martins, C.I.M., E.H. Eding, M.C.J. Verdegem, L.T.N. Heinsbroek, O. Schneider, J.P. Blancheton, E.R. d'Orbcastel and J.A.J. Verreth: New developments in recirculating aquaculture systems in Europe: A perspective on environmental sustainability. Aquaculture Engg., 43, 83-93 (2010).

Metaxa, E., G. Deviller, P. Pagand, C. Alliaume, C. Casellas and J.P. Blancheton: High rate algal pond treatment for water reuse in a marine fish recirculation system: Water purification and fish health. Aquaculture, 252, 92-101 (2006).

Mirzoyan, N., Y. Tal and A. Gross: Anaerobic digestion of sludge from intensive recirculating aquaculture systems: Review. Aquaculture, 306, 1-6 (2010).

Muñoz, R. and B. Guieysse: Algal-bacterial processes for the treatment of hazardous contaminants: A review. Water Res., 40, 2799-815 (2006).

Oswald, W.J., H.B. Gotaas, H.F. Ludwig and V. Lynch: Algae symbiosis in oxidation ponds - III. Photosynthetic oxygenation. Sewage Ind. Waste., 25,692-705 (1953).

Park, J.B.K., R.J. Craggs and A.N. Shilton: Wastewater treatment high rate algal ponds for biofuel production. Bioresour. Technol., 102, 35-42 (2011).

Paul, B.G. and C.R. Vogl: Impacts of shrimp farming in Bangladesh: Challenges and alternatives. Ocean Coast. Manag., 54, 201-211 (2011).

Picot, B., S. Moersidik, C. Casellas and F. De Pharmacie: Using diurnal variations in a high rate algal pond for management pattern. Water Sci. Tech., 28, 169-175(1993).

Rahim, N.A., M. Hasanuzzaman and M. Hasanuzzaman: Energy situation in Malaysia: Present and its future (2012).

De Schryver, P., R. Crab, T. Defoirdt, N. Boon and W. Verstraete: The basics of bio-flocs technology: The added value for aquaculture. Aquaculture, 277, 125-137 (2008).

Shibata, A., Y. Goto, H. Saito, T. Kikuchi, T. Toda and S. Taguchi: Comparison of SYBR Green I and SYBR Gold stains for enumerating bacteria and viruses by epifluorescence microscopy. Aquat. Microb. Ecol., 43, 223-231 (2006).

Shpigel, M. and A. Neori: Microalgae, macroalgae, and bivalves as biofilters in land-based mariculture in Israel. In: Ecological and Genetic Implications of Aquaculture Activities (Ed.: T.M. Bert). Springer Netherlands, Dordrecht, pp. 433-446 (2007).

Suzuki, R. and T. Ishimaru: An improved method for the determination of phytoplankton chlorophyll using $\mathrm{N}, \mathrm{N}$-dimethylformamide. J. Oceanogr. Soc. Japan, 46, 190-194 (1990).

Wang, J.K.: Conceptual design of a microalgae-based recirculating oyster and shrimp system. Aquacultural Engg., 28, 37-46 (2003).

Welschmeyer, N.A.: Fluorometric analysis of chlorophyll $a$ in the presence of chlorophyll $b$ and pheopigments. Limnol. Oceanogr., 39, 1985-1992 (1994).

Wright, P.: Review nitrogen excretion: Three end products, many physiological roles. J. Exp. Biol., 198, 273-281 (1995). 